\title{
Factors Affecting Female Students' Academic Achievement in High School: The Case of Aberuswolkite High School in Ethiopia
}

\author{
FasikaTadesse $^{1}$, Shemelis Zewdie ${ }^{2}$ \& Temesgen Dagne ${ }^{3}$ \\ ${ }^{1}$ Student of Development Management at Ethiopian Civil Service University (ECSU), A. A, Ethiopia \\ ${ }^{2}$ Lecturer in Social Security Management at Ethiopian Civil Service University, A.A, Ethiopia \\ ${ }^{3}$ Deputy Director of Institute of Public Management and Development Studies at ECSU, A.A, Ethiopia
}

\begin{abstract}
Education is one of the social factors where by gender disparity is reflected. In the field of education, the number of educated females is very low. As the grade level in school increases the number of female students starts to decline because of lots of factors. Consequently, higher education remains an area of learning from which women are less represented both as a student and staff. The main objective of this research is to identifying factors affecting female students' academic achievement in Aberuswolkite high school. To do so, to make the sample representative enough; the study used were used as the main tool of data gathering instrument. The findings of this study shows that the decreasing in enrolment, increasing in dropout and class repetition from time to simple random sampling technique school female students through lottery method and purposive sampling techniques for school directors and city education head officer. The study is descriptive type research. Primary and secondary data were used as data source. Questionnaire and structured interview time and different causes were identified such as female students were took household responsibility, and inadequate support from their family, lack of teachers instructional support(regular tutor for female students), inadequate guidance and counseling. All these taken as caused female students poor academic performance in the study area. The core issues were pointed out in the conclusion part of the study and the researcher recommendations are: Motivation program should be organized, Training program should be designed, sufficient budget should allocated, sufficient time should given for female students to do their home work. And the study will help all concerned bodies to understand the causes of the problem under investigation and they should try to solve the problem effectively.
\end{abstract}

Key words: Academic achievement, performance, Female students, Gender

\section{INTRODUCTION}

The proportion of girls enrolled in primary, secondary and higher education has risen considerably throughout the third world. However, there are still substantial gaps between the number of girls and the number of boys enrolled in formal education. In particular, it appears that the gap is narrowing in much of Latin America but growing in Africa and in part of Asia. In general, girls were still more likely than boys to dropout earlier from the education pipeline. While in same country girls make up 50\% of primary-school enrolment, a small percentage continue on for secondary schooling, and even fewer pursue tertiary numbers of students attending such institution (Nelly P. 1998).

In most developing countries all children are required to, and do, attend school. In developing countries this is not always the case even when schooling is available it is often difficult to get to and expensive to participate. Even where schooling is free girls attend less due to other factors. Even if schooling is free there may be a cost from the loss of the children labor in the field, home or work place. Other factors mitigate against the inclusion of girls in education in developing countries, especially for females with limited no resource (Marchbank \& Lether, 2007).

The rats of completion of secondary education by gender do not always favor boys and, in addition boys and girls may drop out of education for different reasons (Dunne et al. 2005). It was fund that more girls than boys drop out of the school before completing their education due in the main to pregnancy and early marriage (Ibid).

Gendered experiences outside of schooling have always been found to cause girls to drop out, in particular gender based violence, both in the community and with in school, along with the prevalence of sexually transmitted diseases all militate against girls finishing their education (Marchbank \& Lether, 2007). Education is one of the

${ }^{1}$ Corresponding Author: shemelisz@gmail.com 
social factors where by gender disparity is reflected. In the field of education, the number of educated females is very low. As the grade level in school increases the number of female students starts to decline because of lots of factors. Consequently, higher education remains an area of learning from which women are less represented both as a student and staff. The New Education and Training Policy (1994) various strategies are employed to increase females' enrollment in all levels of education.

Although Ethiopia's education and training policy stresses the need to sensitize society about the importance of girls' education, it has nevertheless a long way to go in making its dream come true. Girls who happen to go to school are expected to take care of household chores as well when they return home, leaving them with no time to study or do their homework. This results in poor school achievement, often resulting in failure. The problem of poverty and that of girl students have always been acute in Ethiopia. The majority of girls fail to attend school because of early marriages, pregnancies and sexual harassment (https://www.google.com.et/) [accessed on November 15/2014, at $8: 25 \mathrm{pm}]$.

The study area which the researcher focuses on female students' academic achievement according to Aberuswolkite high school yearly report (2002-2006 E.C) was lower than that of male students. The researcher strives to identify the reason behind the problem. This study was identified factors affecting female students' academic achievement in the case of AberusWolkite high school in Wolkite city administration.

\section{Statement of the Problems}

Female education is recognizing as one of the critical path way to promote social and economic development as well as a means to enhance women's in development efforts effectively and meaningfully. Evidence in Ethiopia indicate that's due to some change in government policies there have been improvements in female participation in education, however, access to education remains limited and repetition and dropout rate of female students remains high in this study area. It is evident that, among enrolled students the dropout rate for Female in Ethiopia much higher than that of Boys.

\subsection{Research Questions}

What are the factors that challenge the female students' academic achievement in high school?

What are the main problems of female students in high school?

What is the trend of enrolment, dropout, and repetition rate of female student in high school?

\section{OBJECTIVES OF THE STUDY}

\subsection{General Objective}

The general objective of the study is to assess the factors affecting female students' academic achievement in education at high school level of Aberuswelkite high school in Ethiopia.

\subsection{Specific Objectives}

$>$ To identify the factors that challenges the female students' academic achievement.

$>$ To find out the main problems of female students in the educational achievement.

$>$ To assess the trend of female enrolment, dropout and class repetition rate in the Aberuswelkite high school over the last five years.

\section{REVIEW OF RELATED LITERATURE}

The availability of school may reflect community demand for schools, even though to each family the availability of place a supply or cost factor in its decision about schooling The role of women and development is most intimately related to the goal of comprehensive socio-economic development, and is a strategic question for the development of all societies. Any development strategy which neglects the need for enhancing the role of women cannot lead to comprehensive socio-economic development. The point of departure is to recognize the role of women as a dynamic factor and the valuable asset for the overall process of development it is not a burden or cost nor a mere humanitarian concession to a disadvantage group (Roy, 2003).

The scattered, piecemeal or curative, approach to the advancement of women view women as passive subject of protection or as recipients of marginal welfare and social service, unrelated to policies and strategies for economic development or the structural changes in societies that result from economic changes. Such approaches have failed 
to prevent the growing marginalization of women in the economy and in the political process in most developing, and even developed countries. In the absence of an integrated approach to development, a fragmentary approach to the position of women in development has been perpetuated and has led to the unsatisfactory option of promoting the advancement of women by social welfare, humanitarian and demographic approach, without due attention to the transformations needed to create conditions in which women can unfold their full potential as a factor of development. These approaches should now be replaced by a integrated and participatory approach which relates to the role of women in development, their aspiration and needed to the critical areas, issues and choices in the developmental strategy for economic growth, a more human use of material and human resource, and for equity in power relation at the national and international level (Kumar, 2002). New investigations are raising our estimates of how much time and labor children contribute to the economy of the house hold. Often the burdens placed on girl exceed e for boys. Children child care and household tasks do not exhaust girls' contribution to family economic, they may work in garden or field, fetching and carrying, or help in trade and do more processing of products for sale. Time spent by girl in these activities can be especially important in poorer families where perceptions of benefits from the schooling of girls are dimmer (Roy, 2003).

Education is the process by which a nation transform itself from what it is, in to what it is aspires to be. It is perhaps the most important aspects of the evaluation and maintenance of a nation. Education is the backbone of social development. The extent and shape of development is determined by social and cultural patterns. In primitive communities social and cultural patterns were of a sample nature and factor influencing the state of education were few and clearly defined. But sophisticated communities those factors are numerous and complex. Education satisfies the need of society by developing human material and drafting. This material in to the nations services (Bhuimali. \& Podder., 2005).

In a number of developing countries, the participation of women in education is characterized by low enrolment and poor performance. The significant contribution of female education is expressed in terms of economic, cultural and political aspect a country. an educated female is likely to become: a more competent and knowledgeable mother, a more productive and better paid worker, an informed citizen, a self confident individual and a skilled decision maker (Tadesse, 2009).

Education empowers them to participate in the public and political life. The potential benefits of education are always present but females' education often has stronger and more significant impact than males' education. This does not mean education is unnecessary for males. One of the Ethiopia's research efforts pointed out that girl's low level of school attainment and correspondingly low levels of literacy, political integration, and economic productivity (Ibid).

With regard to the importance of educating women for poor countries like Ethiopia in as much as women constitute at least one half of the total population of the nation, the question of women's education can no longer be ignored, and their involvement in the development process should not be left to be marginal. After all, a developing country like Ethiopia, cannot afford the luxury of not using the brainpower, and talent of both sexes in the productive labour. Moreover, it could be realized that the question of the emancipation of women is inextricably linked with their education and in fact their freedom could be said to be the function of their level of participation in education (Tadesse, 2009).

\section{RESULTS}

In the study the data were commented from questionnaires were analyzed and were indicated in percentages.

\subsection{Factors For Female Students Academic Achievement}

Table5.1. Response related to female students

\begin{tabular}{|c|c|c|c|c|}
\hline \multirow{2}{*}{ No. } & \multirow{2}{*}{ Item } & \multirow{2}{*}{ Response Categories } & \multicolumn{2}{|l|}{ Responses } \\
\hline & & & Frequency & Percentage \\
\hline \multirow{3}{*}{1} & \multirow{3}{*}{ Is it safe to travel to school? } & Yes & 47 & 87.04 \\
\hline & & No & 7 & 12.96 \\
\hline & & Total & 54 & 100 \\
\hline \multirow[t]{3}{*}{2} & \multirow{3}{*}{ Do you work your home work Properly? } & Yes & 6 & 11.11 \\
\hline & & No & 48 & 88.89 \\
\hline & & Total & 54 & 100 \\
\hline \multirow{3}{*}{3} & \multirow{3}{*}{ Are there dropout female students in your local area? } & Yes & 26 & 48.15 \\
\hline & & No & 8 & 14.81 \\
\hline & & I don't know & 20 & 37.04 \\
\hline
\end{tabular}


American Research Journal of Humanities and Social Sciences, Volume 1, Issue 4, 2015

ISSN 2378-7031

Source: primary data, 2015

Total

54

100

Table 5.2: Female students' response about improvement of their academic performance

\begin{tabular}{|l|l|l|l|}
\hline Item & Categories of responses & \multicolumn{2}{l|}{ Frequency } \\
\cline { 3 - 4 } & & No. & Percent \\
\hline In order to improve the academic performance of female & Motivate teacher & 5 & 9.3 \\
\cline { 2 - 4 } students the role of school should be & $\begin{array}{l}\text { Solve problem of female } \\
\text { students }\end{array}$ & 33 & 61.11 \\
\cline { 2 - 4 } & $\begin{array}{l}\text { Facilitate the school } \\
\text { instructional process }\end{array}$ & 16 & 29.63 \\
\cline { 2 - 4 } & Total & 54 & 100 \\
\hline
\end{tabular}

Source: Primary data, 2015

TTable 5.3: Reasons facing for female students class repetition

\begin{tabular}{|l|l|l|l|}
\hline Item & Categories of responses & \multicolumn{2}{l|}{ Frequency } \\
\cline { 3 - 4 } & & No. & Percent \\
\hline \multirow{2}{*}{$\begin{array}{l}\text { Which reasons are facing for repetition of } \\
\text { the class? }\end{array}$} & Lack of teachers support & 25 & 46.3 \\
\cline { 2 - 4 } & Lack of guidance and counseling & 15 & 27.78 \\
\cline { 2 - 4 } & $\begin{array}{l}\text { Lack of enough role of female teachers in the } \\
\text { school }\end{array}$ & 14 & 25.93 \\
\cline { 2 - 4 } & Total & 54 & 100 \\
\hline
\end{tabular}

Source: primary data, 2015

\section{Main problems of female students at the school}

Table 6.1: school related factors affect effective participation offemale students in the study area.

\begin{tabular}{|c|c|c|c|c|c|c|c|c|c|c|c|}
\hline \multirow{3}{*}{$\begin{array}{l}\mathrm{N} \\
\mathrm{o}\end{array}$} & \multirow{3}{*}{ Factors } & \multicolumn{10}{|c|}{ Frequency of responses } \\
\hline & & \multicolumn{2}{|c|}{ V. high } & \multicolumn{2}{|c|}{ High } & \multicolumn{2}{|c|}{ Medium } & \multicolumn{2}{|c|}{ Low } & \multicolumn{2}{|c|}{ V. low } \\
\hline & & $\mathrm{No}$ & $\%$ & No & $\%$ & No & $\%$ & No. & $\%$ & $\mathrm{No}$ & $\%$ \\
\hline 1 & School distance & 3 & 5.6 & 10 & 18.5 & 25 & 46.3 & 10 & 18.5 & 6 & 11.1 \\
\hline 2 & $\begin{array}{l}\text { Lack of guidance \& } \\
\text { counseling }\end{array}$ & 3 & 5.6 & 20 & 37.03 & 13 & 24.07 & 11 & 20.37 & 7 & 12.96 \\
\hline 3 & $\begin{array}{l}\text { The proportional } \\
\text { female teachers }\end{array}$ & - & - & 2 & 3.7 & 8 & 14.81 & 24 & 44.44 & 20 & 37.03 \\
\hline 4 & hool facilities & 4 & 7.4 & 4 & 7.4 & 22 & 40.74 & 12 & 22.22 & 12 & 22.22 \\
\hline 5 & $\begin{array}{l}\text { Different attention to } \\
\text { girls by teachers }\end{array}$ & 1 & 1.85 & 7 & 12.96 & 23 & 42.59 & 14 & 25.92 & 9 & 16.67 \\
\hline 6 & $\begin{array}{l}\text { Sexual violence } \\
\text { harassment by male } \\
\text { students }\end{array}$ & 4 & 7.4 & 6 & 11.1 & 26 & 48.15 & 4 & 7.4 & 4 & 7.4 \\
\hline 7 & $\begin{array}{l}\text { Sexual violence } \\
\text { harassment by male } \\
\text { teachers }\end{array}$ & 2 & 3.7 & 2 & 3.7 & 6 & 11.1 & 12 & 22.2 & 32 & 59.26 \\
\hline
\end{tabular}

Source: primary data, 2015

\section{Conclusion}

Education contributes to socio-economic development by endowing individuals with the means of to improve their health, skills, knowledge and capacity for productive work. Moreover, investment in the education of 
women leads to better child health, lower fertility and reduce maternal mortality. This is why the society has to take different measure to improve the participation of female in education.

achievement such as inadequate time given for doing their home work by parents, weak teachers instructional support(tutorial), school facilities(girls library), lack of guidance and counseling, sexual harassment by male students, the absence of adequate role model female teachers are analyzed and interpreted. All these factors affect female students' academic achievement. If these factors continued, for long time one part of achievement in educational goal would be failed. Since the problem must be solved.

The study tried to see the participation of female in education over the past five years. As the research result indicates female students academic achievement was poor. The problem has different factors. Academic advising problem, unfavorable school environment (this implies that the school social climate is not comfortable for female students which significantly affect their academic achievement), lack of adequate effort from themselves and luck of family and community commitment to female education are some of factors that cause females' poor academic achievement. However all these problems are not beyond the capacity of stakeholders and it should have resolved.

$>$ The trends of enrolment, dropout and repetition rate were analyzed seriously. The research result shows that decreasing enrolment rate and both dropout and repetition rate were increasing. These problems lead to social, financial and material crises. As the researcher perception these problems should be solved, because educating female is educating family as well as educating society. If society educated well, sustainable development will assured.

\section{RECOMMENDATIONS}

Recommendation of the study focuses on measure to be taken in the future to improve female students' academic achievements.

Organizing study class, female students' library, girls club for female students also can increase their participation in education because many families do not allow female students to study with male students. This will decrease repetition rate of female students and discourage other females to be enrolled to school. School environment should comfortable for girls' physical and psychological wellbeing. Therefore school community should finance budget and build special dressing classes and recreation area.

Motivation program should be organized for high achiever female students and their parents, teachers who participate on female issue, parents and role model female teachers as well as female students- teachers committee to increase their motivation. It is also important to incorporate the activities of improving female students' participation in education in to teachers' performance management program as an element.

Training program should be designed for female students- teachers committee, school administration staff and teachers on counseling technique, gender issue and management skills.

$>$ Improving female academic achievement is not only the responsibility of school but also the responsibility of all those who work for the well being of the society. However if, they are work individually they will face many problems that can limit their achievement. Therefore, all those working on improving the achievement of female student's education should carry their activities in coordination with each other.

$>$ Allocation of sufficient budget for intervention at city and school level will enable to take measure in sufficient and effective manners factors that affecting female students academic achievement are complex and intertwined and require holistic intervention. Therefore, sufficient budget should be allocated and the main factors should be tackled in both demand and supply side by attracting NGOs and mobilizing society they can increase the budget allocate for interventions designed to increase to female participation in education.

$>$ Female student must be made to believe that they should offer as mach sufficient time to their home work as is given to other activities.

$>$ Parents should be made to believe that their daughters are the same as their sons in intelligence. They should also backup their daughters to achieve success in their education.

\section{REFERENCES}

[1] Bhuimali A. \&podder S., (2005). Development of rural women through education and empowerment. India. Published by J.K singn for Abhijeet publications. 
American Research Journal of Humanities and Social Sciences, Volume 1, Issue 4, 2015

ISSN 2378-7031

[2] http://www.genderismyagenda.com/country_reports/states_reports_eng/ethiopia_report.pdf [accessed on November $15 / 2014$, at $8: 25 \mathrm{pm}]$

[3] https://www.google.com.et/?gws_rd=ssl\#q=ethiopian+female+students [accessed on November 15/2014, at 8:25 pm]

[4] Jha Shankar U,(2004), Gender and Social order issuesand challenges(2ndedn).Pubilished bymodern sachdeva, Delhi.

[5] Kothari C.R. (1985). Research methodology: Methods and techniques (2nd edn). New Delhi. Published by V.S.Joyri for WishwaPrakashan.

[6] Kumar A. (2002).Women and development process.published by prabhotkumar Sharma, for sarup\& sons, laser Typesetting at man as typesetter, 4648/1,21,Darya,Ganj,New Delhi

[7] Marchbank J.\&Letherby.G,(2007). Introduction to gender: social science perspective England. Pearson education limited.

[8] Pandey A.K, (2002). Emerging issues in empowerment of women. New Del hi J.L. Kumarfor Anmol publications put Ltd.

[9] PHRD(1996), Ethiopian social studies: Education sector review, Addis Ababa; PHRDPO

[10] Roy A, (2003). Developmentof women: an assessment, published by Mrs. Seema, New Delhi stromquls,

[11] StromquistP.Nelly(1998). Women in the third world: an encyclopedia of laytemporary issues. New York Garland publishing, Inc.

[12] TadesseShiferaw (2009).Understanding Female Students' Academic Performance: An Exploration of the Situation in South Nations Nationalities and Peoples.The Hague, The NetherlandsAvailable athttps://www.google.com.et/search?q=factors +affecting +female+students[Accessed on6 January 2015]

[13] TekluTafase(2013).Gender disparity in academic achievement.Jimma College of Teacher Education. Vol. 9 No 1 September $2013 \quad$ Available athttp://www.juedu.et/ejes/sites/ default/files/Disparity\%20in\%20academic\%20achievement.pdf[Accessed on 7 January 2015]

[14] Yeshimebrat M. et al., (2013).Factors Affecting Female Students' Academic Achievement at Bahir Dar University, Ethiopia.CICE Hiroshima University, Journal of International Cooperation in Education, Vol.15 No.3 (2013) pp.135 148

[15] Yeshimebrat M.et al., (2009). The Study of Policy Intervention on Factors Affecting Female Students' Academic Achievement and Causes of Attrition In Higher Learning Institutions of Ethiopia.

[16] http://info.moe.gov.et/gendocs/Gender.pdf [accessed on November 15/2014, at 8:25 pm] 